\title{
Enzymatic hydrolysis of palm oil mill effluent solid using mixed cellulases from locally isolated fungi.
}

\begin{abstract}
In order to optimize the enzymatic hydrolysis of POME solid, the effects of substrate pretreatment using varying concentrations of sodium hydroxide and sulfuric acid, crude enzyme from both strains in different ratio and $\mathrm{pH}$ reaction were studied. The best experimental conditions found to degrade POME solids were $12 \mathrm{~h}$ incubation time, $0.5 \%$ (v/v) sulfuric acid pretreatment, crude enzymes mixture from Aspergillus niger EB5 and Trichoderma sp. EB6 $(1.75 \mathrm{~mL}$ Asp+0.25 mL Tri with the total cellulase activity equal to $14.76 \mathrm{IU})$ and incubation $\mathrm{pH}$ at 5.0. Under these conditions, the reducing sugar concentration reached $23 \mathrm{~g} \mathrm{~L}-1$ with the hydrolysis yield and productivity at $32 \%$ and $1.90 \mathrm{~g} \mathrm{~L}-1 \mathrm{~h}-1$, respectively. The bioconversion of POME solid to reducing sugar by the mixture of crude enzyme from the strains was relatively higher by almost 2 folds as compared to commercial cellulase. The results suggested that the crude cellulases mixture from locally isolated fungi has potential for hydrolyzing the abundant agriculture residues from the palm oil industry.
\end{abstract}

Keyword: Enzymatic hydrolysis; POME; Aspergillus niger EB5; Trichoderma sp EB6; Cellulases. 